\title{
The Periodontal Status of Boys 11 to 17 Years Old in Bombay, India
}

\author{
by Sigurd P. Ramfjord, L.D.s., M.s., PH.D.," Ann Arbor, Michigan
}

T investigation had the following objectives:

1. To train investigators for epidemiological studies of periodontal disease in India;

2. To initiate a study of the prevalence and incidence of periodontal disease, with special reference to early destructive periodontal disease;

3. To relate various etiologic factors to the prevalence and severity of the periodontal disease;

4. To investigate whether or not periodontal disease in India is of a different nature or type than periodontal disease in the Western world;

5. To gain information that could serve as a basis for planned management and prevention of periodontal disease.

A review of the literature pertinent to the planning of this study has been published previously. ${ }^{1}$

\section{MATERIAL AND METHOD}

Since one of the main purposes of this investigation was to study the initial phase of destructive periodontal disease in the

*The University of Michigan School of Dentistry, Ann Arbor, Michigan.

This investigation was sponsored jointly by the World Health Organization and the government of India during the summer of 1957. A detailed report was submitted to W.H.O. in December, 1958. A large number of persons participated in the organization and execution of this study, but space will allow acknowledgment only to a few who especially devoted time, interest, and untiring effort towards the completion of the project: From W.H.O., Dr. C. L. Sebelius; from India, Colonel N. N. Bery, Drs. H. D. Merchant, K. L. Shourie, M. K. Basu, R. P. Dastur, N. T. Desai, B. R. Kankaria, (Miss) S. V. Koppikar, (Miss) M. A. Malaowalla, S. B. Sathe, S. B. Vaid; from the U. S. Public Health Service, Dr. J. C. Greene. permanent dentition, it was decided to examine age groups between 11 and 17 years. According to local authorities in Bombay, it was more expedient to select boys for the survey than girls since the boys were attending school more regularly than girls. By studying only boys the problem of possible differences in periodontal scores associated with the difference in sex if mixed groups were examined could be avoided.

An attempt was made to examine urban and rural groups of equal size and comparable age. The selected population groups were all living under very poor economic conditions. Urban public schools in the cotton mill district of Bombay provided the urban sample. The rural population groups were made up of boys from public and missionary schools in the Bassein Road area, about 40 to 50 miles from the center of Bombay. This area is an agricultural district (rice and bananas) but, being situated so close to the city of Bombay, the economic and social standards cannot be accepted as typical of rural India.

In the 11-year group were included boys who were 11 years of age or older but had not reached the age of 12 at the date of the examination. The 13,15, and 17-year old groups were formed in the same way. All of the boys within these age groups were examined in every school visited. The cooperation from the school authorities, teachers, and children was excellent. The examination usually was done on open balconies without artificial light, and with instruments described in a previous article. ${ }^{1}$

Eight Indian dentists participated in the examination procedures. Each boy within the selected age group was examined twice in order to complete a Russell-Greene scoring under Dr. Greene's supervision ${ }^{2}$ and another scoring according to the system 
TABLE I

Periodontal Disease, Calculus, Plaque, and Attrition Scores

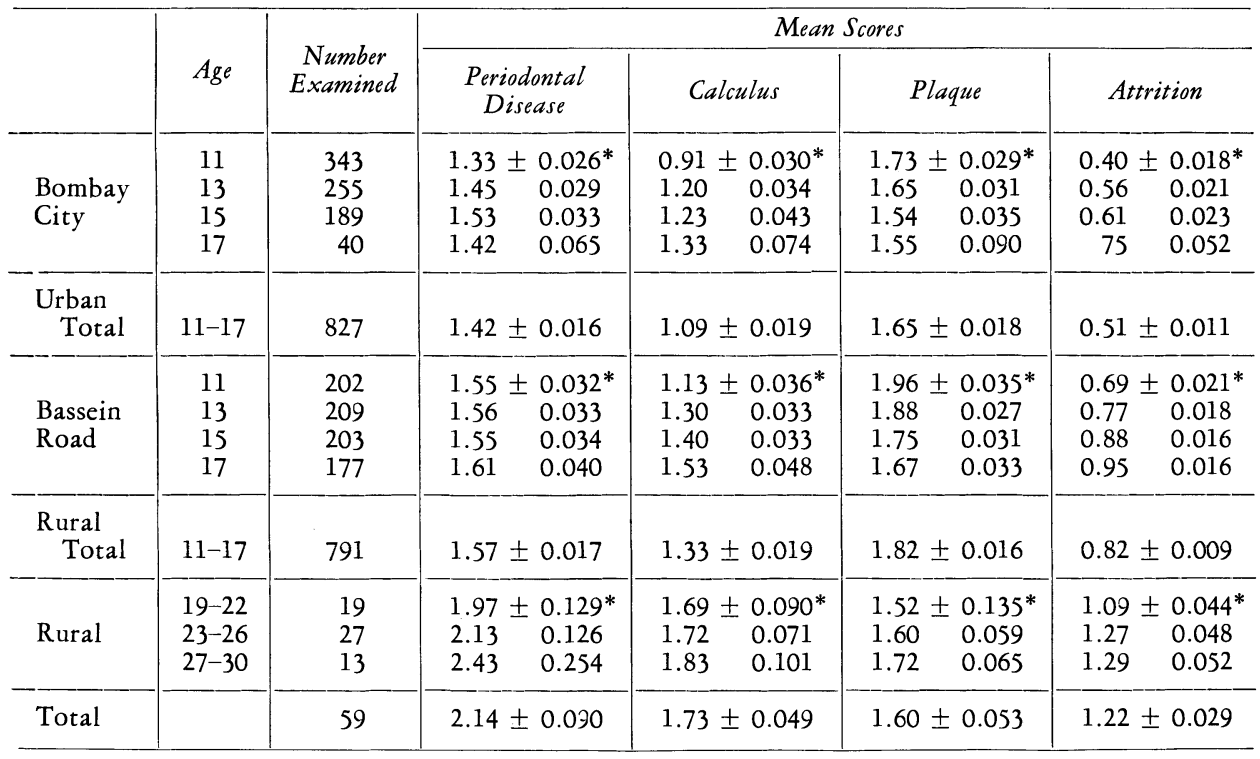

*Standard Error

suggested by Ramfjord. ${ }^{1}$ An attempt was made to familiarize the examiners with both systems and to let them practice each scoring system.

The findings obtained according to the Russell-Greene system have been published by Dr. Greene. ${ }^{2}$ His article is referred to for comparison with the findings reported here following the use of the periodontal disease index (P.D.I.) described by Ramfjord. ${ }^{1}$

The main survey included 827 boys from Bombay City and 791 boys from the Bassein Road district. In addition, 59 males, 19 to 30 years old, were examined at a teacher's college in the Bassein Road district.

\section{FINDINGS}

Table I is a compilation of all recordings with regard to periodontal disease, calculus, plaque, and attrition.

A trend for periodontal disease to increase slowly in severity with increasing age is apparent from this table. An exception to this trend seems to be the 17-year old boys in the urban section. There also appears to be a statistically significant difference at the one per cent level between the severity of periodontal disease in the rural and urban populations for most age groups with the rural groups having the highest scores. A similar difference also was reported by Greene. ${ }^{2}$ However, some modifying factors should be considered in order to understand and evaluate this difference.

1. The urban examinations were done first. The examiners were not well trained, and the ability to observe periodontal disease increases with the experience of the examiner.

2. Three examiners from the urban study did not participate in the rural study. One examiner, whose scores were consistently far below average in the urban study, was used as interpreter and thus practically eliminated from examination of subjects in the rural study (examined only 6 boys).

In order to minimize the examiner difference, Table II was compiled. Only the findings of three examiners (including the 
TABLE II

Periodontal Disease, Calculus, Plaque and Attrition Scores by the Three Most Consistent Examiners

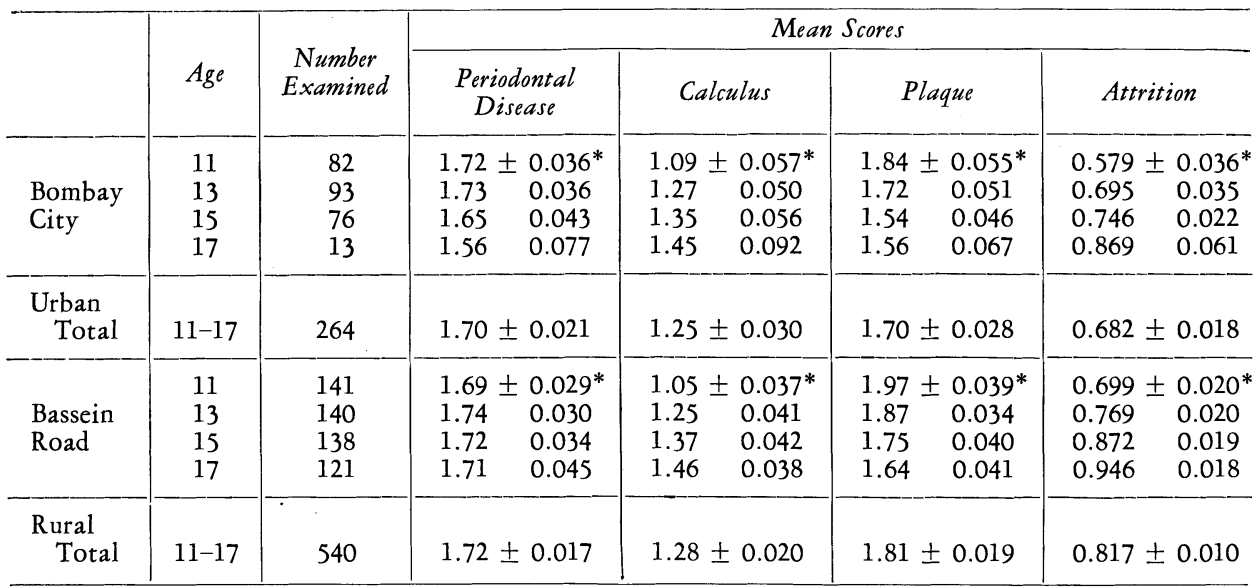

*Standard Error

writer) whose scores were very similar have been included. According to this table there is only a slight but non-significant difference between the periodontal disease scores of the urban and rural boys.

A gradual increase in accumulation of calculus with age is evident in both Tables I and II. However, the statistically significant difference (at the one per cent level of confidence) in Table I between the rural and urban groups appears as an insignificant difference in Table II, indicating only slightly more calculus in the rural than in the urban group.

The scores for stainable dental plaques gradually decline with an increase in age from 11 to 15 years in the urban boys and from 11 to 17 years of age in the rural boys according to Tables I and II. The plaque scores are also significantly higher in the rural than in the urban groups (some at the 5 per cent level and some at the one per cent level).

A gradual increase in attrition with age is obvious from both Tables I and II. There is also a highly significant difference in attrition between the rural and urban groups of the same age. The rural groups consistently exhibit more occlusal and incisal wear than the urban groups. No attempt was made to study the possible dietary background for the higher attrition scores in the rural groups.

At the bottom of Table I are listed the scores from a pilot study of men 19 to 30 years of age. This limited material was divided in age groups of four-year intervals: 19 through 22 years, 23 through 26, and 27 through 30 years of age. From this table, it appears that periodontal disease slowly increases in severity (amount of periodontal destruction) with increase in age. A slow gradual increase also is evident for the calculus, plaque, and attrition scores. It is interesting to note that the level of plaque appears to reach a low at 15 to 19 years of age, seemingly somewhat earlier in the urban than in the rural population, and then the score gradually increases with age.

The entire material was analyzed with reference to prevalence of periodontal disease, periodontal pockets, and gingival recession (Table III). This table demonstrates drastically the magnitude of the problem of periodontal disease in India since practically 100 per cent of all individuals examined had periodontal disease. From this table, it also appears that periodontal pockets are initiated after the age of 15 years. The very few individuals who had true periodontal pockets or gingival 
TABLE III

Persons with Periodontal Disease, Periodontal Pockets and Recession (Urban and Rural)

\begin{tabular}{|c|c|c|c|c|c|c|c|}
\hline \multirow[t]{2}{*}{ Age } & \multirow{2}{*}{$\begin{array}{c}\text { Number } \\
\text { Examined }\end{array}$} & \multicolumn{2}{|c|}{$\begin{array}{c}\text { Persons with } \\
\text { Periodontal } \\
\text { Disease }\end{array}$} & \multicolumn{2}{|c|}{$\begin{array}{l}\text { Persons with } \\
\text { Periodontal } \\
\text { Pockets }\end{array}$} & \multicolumn{2}{|c|}{$\begin{array}{l}\text { Persons with } \\
\text { Recession }\end{array}$} \\
\hline & & Number & Percent & Number & Percent & Number & Percent \\
\hline 11 & 542 & 539 & 99.4 & 4 & 0.7 & 3 & 0.6 \\
\hline 13 & 464 & 464 & 100.0 & 3 & 0.6 & 1 & 0.2 \\
\hline 15 & 392 & 392 & 100.0 & 8 & 2.0 & 4 & 1.0 \\
\hline 17 & 217 & 217 & 100.0 & 20 & 9.2 & 7 & 3.2 \\
\hline $\begin{array}{c}19-22 \\
\text { (mean 20.6) }\end{array}$ & 19 & 19 & 100.0 & 6 & 31.6 & 3 & 15.8 \\
\hline $\begin{array}{c}23-26 \\
\text { (mean } 24.0)\end{array}$ & 27 & 27 & 100.0 & 13 & 48.1 & 7 & 25.9 \\
\hline $\begin{array}{c}27-30 \\
\text { (mean 28.3) }\end{array}$ & 13 & 13 & 100.0 & 6 & 46.2 & 6 & 46.2 \\
\hline
\end{tabular}

recession before the age of 15 had these anomalies in association with marked malposition of the teeth, and the epithelial attachment was situated only slightly apical to the cementum-enamel junction. At the age of 17 , more than 9 per cent of the individuals examined had periodontal pockets, and in the small group of 19 to 22 year old individuals, 31.6 per cent had periodontal pockets. Much larger population groups have to be examined before significant results can be obtained relative to the progress of periodontal disease in individuals older than 17 years of age. However, it is interesting to note the great increase in gingival recession with age. From clinical observation, it was obvious that this recession was due to horizontal rubbing over the teeth with the fingers for the purpose of oral hygiene. This procedure was often accompanied by the use of sharp abrasives (ashes or abrasive tooth powders), producing wide " $U$ " shaped notches on the labial gingival aspect of the teeth, especially in the maxilla in persons older than 25 to 30 years of age.

The gingivitis score for the individual teeth in the various age groups is recorded in Table IV. The recorded mandibular lower incisor (tooth \#25) consistently showed the most severe gingivitis in its surrounding tissues. The next highest score for gingivitis was found around the maxillary first molar (tooth \#3), while the lowest score for gingivitis was found around the mandibular first bicuspid (tooth \#28). A slight decrease in the mean score for gingivitis from 15 to 17 years of age is consistent with the reports from other surveys of prevalence of periodontal disease. $^{3-7}$

The distribution of the periodontal pockets is recorded in Table $\mathrm{V}-\mathrm{A}$. It is

TABLE IV

Gingivitis Score for Individual Teeth (Urban and Rural)

\begin{tabular}{c|c|c|c|c|c|c|c|c}
\hline Age & $\begin{array}{c}\text { Number } \\
\text { Ex.mined }\end{array}$ & $\begin{array}{c}\text { Tooth } \\
\# 3\end{array}$ & $\begin{array}{c}\text { Tooth } \\
\# 9\end{array}$ & $\begin{array}{c}\text { Tooth } \\
\# 12\end{array}$ & $\begin{array}{c}\text { Tooth } \\
\# 19\end{array}$ & $\begin{array}{c}\text { Tooth } \\
\# 25\end{array}$ & $\begin{array}{c}\text { Tooth } \\
\# 28\end{array}$ & $\begin{array}{c}\text { Mean } \\
\text { Gingivitis }\end{array}$ \\
\hline 11 & 542 & 1.48 & 1.27 & 1.30 & 1.38 & 1.69 & 1.09 & 1.40 \\
13 & 464 & 1.62 & 1.40 & 1.47 & 1.51 & 1.81 & 1.13 & 1.49 \\
15 & 392 & 1.60 & 1.43 & 1.46 & 1.55 & 1.87 & 1.27 & 1.53 \\
17 & 217 & 1.63 & 1.39 & 1.50 & 1.50 & 1.89 & 1.25 & 1.50 \\
\hline
\end{tabular}


TABLE V-A

Individual Teeth with Periodontal Pockets (Urban and Rural)

\begin{tabular}{c|c|c|c|c|c|c|c|c}
\hline Age & $\begin{array}{c}\text { Number } \\
\text { of Cases }\end{array}$ & $\begin{array}{c}\text { Tooth } \\
\# 3\end{array}$ & $\begin{array}{c}\text { Tooth } \\
\# 9\end{array}$ & $\begin{array}{c}\text { Tooth } \\
\# 12\end{array}$ & $\begin{array}{c}\text { Tooth } \\
\# 19\end{array}$ & $\begin{array}{c}\text { Tooth } \\
\# 25\end{array}$ & $\begin{array}{c}\text { Tooth } \\
\# 28\end{array}$ & $\begin{array}{c}\text { Total Number of } \\
\text { Teeth with } \\
\text { Periodontitis }\end{array}$ \\
\hline 11 & 542 & 0 & 1 & 0 & 0 & 3 & 0 & 4 \\
13 & 464 & 0 & 0 & 1 & 0 & 2 & 0 & 3 \\
15 & 392 & 0 & 0 & 2 & 1 & 5 & 0 & 8 \\
17 & 217 & 8 & 2 & 4 & 4 & 9 & 1 & 28 \\
\hline
\end{tabular}

evident that the greatest number of periodontal pockets were found around tooth \#25 which, according to Table IV, also showed the highest score for gingivitis. Tooth \#3, which had the next highest score for gingivitis, also had the next highest number of periodontal pockets. Tooth \#28, which had the lowest score for gingivitis, had the lowest number of periodontal pockets. In the 17-year old group, periodontal pocket formation had been initiated around one or more of the teeth included in the examination in one or more individuals.

Gingival recession is recorded in Table $\mathrm{V}-\mathrm{B}$. The figures for recession were low in these young age groups, and the recession usually was found in association with severe malposition of the teeth and most often where the lower incisors were in extreme labial version.

Tables VI-A and VI-B respectively show the amount of calculus on the individual teeth and the percentage of teeth with calculus of all the teeth examined within the various groups. The mandibular lower incisor (tooth \#25) is leading both in regard to amount of calculus and in percentage of teeth with calculus. The calculus deposition on tooth \#3 shows the next highest figures, and the lowest score for calculus was found on tooth \#28. Note the steady increase in amount of calculus and number of teeth with calculus with increase in age as evident from Tables VI-A and VI-B.

The distribution of bacterial dental plaques is recorded in Tables VII-A and VII-B. A slight decrease in the amount of plaque on the teeth with age can be observed from Table VII-A. This decrease is found mainly in the age groups from 11 to 15 years of age, and it was observed clinically to be associated with plaque removal on the labial aspect of the teeth by rubbing the teeth with the finger tip and some abrasive. On the other hand, it is evident from Table VII-B that the percentage of teeth with bacterial plaques increased with age until it involved 95 to 100 per cent of all of the teeth examined.

Table VIII shows the mean scores for attrition, mobility, and open contact for the entire material. A gradual increase in attrition with age is evident from this

TABLe V-B

Individual Teeth with Recession (Urban and Rural)

\begin{tabular}{c|c|c|c|c|c|c|c|c}
\hline Age & $\begin{array}{c}\text { Number } \\
\text { of Cases }\end{array}$ & $\begin{array}{c}\text { Tooth } \\
\# 3\end{array}$ & $\begin{array}{c}\text { Tooth } \\
\# 9\end{array}$ & $\begin{array}{c}\text { Tooth } \\
\# 12\end{array}$ & $\begin{array}{c}\text { Tooth } \\
\# 19\end{array}$ & $\begin{array}{c}\text { Tooth } \\
\# 25\end{array}$ & $\begin{array}{c}\text { Tooth } \\
\# 28\end{array}$ & $\begin{array}{c}\text { Total Number of } \\
\text { Teeth with } \\
\text { Recession }\end{array}$ \\
\hline 11 & 542 & 0 & 0 & 0 & 0 & 2 & 0 & 2 \\
13 & 464 & 0 & 0 & 0 & 0 & 2 & 0 & 2 \\
15 & 392 & 0 & 0 & 0 & 0 & 4 & 0 & 4 \\
17 & 217 & 2 & 1 & 1 & 0 & 0 & 5 & 9 \\
\hline
\end{tabular}


TABLE VI-A

Calculus Score for Individual Teeth (Urban and Rural)

\begin{tabular}{c|c|c|c|c|c|c|c|c}
\hline Age & $\begin{array}{c}\text { Number } \\
\text { Examined }\end{array}$ & $\begin{array}{c}\text { Tooth } \\
\# 3\end{array}$ & $\begin{array}{c}\text { Tooth } \\
\# 9\end{array}$ & $\begin{array}{c}\text { Tooth } \\
\# 12\end{array}$ & $\begin{array}{c}\text { Tooth } \\
\# 19\end{array}$ & $\begin{array}{c}\text { Tooth } \\
\# 25\end{array}$ & $\begin{array}{c}\text { Tooth } \\
\# 28\end{array}$ & $\begin{array}{c}\text { Mean } \\
\text { Calculus }\end{array}$ \\
\hline 11 & 542 & 1.23 & .90 & .62 & 1.04 & 1.37 & .43 & .99 \\
13 & 464 & 1.56 & 1.24 & 1.05 & 1.31 & 1.66 & .63 & 1.25 \\
15 & 392 & 1.50 & 1.29 & 1.17 & 1.45 & 1.62 & .91 & 1.48 \\
17 & 217 & 1.65 & 1.47 & 1.50 & 1.56 & 1.66 & 1.11 & 1.53 \\
\hline
\end{tabular}

TABLE VI-B

Individual Teeth with Calculus (Urban and Rural)

\begin{tabular}{|c|c|c|c|c|c|c|c|c|c|c|c|c|c|}
\hline \multirow[b]{2}{*}{ Age } & \multirow[b]{2}{*}{$\begin{array}{l}\text { Number } \\
\text { Examined }\end{array}$} & \multicolumn{2}{|c|}{ Tooth \#3 } & \multicolumn{2}{|c|}{ Tooth \#9 } & \multicolumn{2}{|c|}{ Tooth \#12 } & \multicolumn{2}{|c|}{ Tooth \#19 } & \multicolumn{2}{|c|}{ Tooth \#25 } & \multicolumn{2}{|c|}{ Tooth \#28 } \\
\hline & & $\begin{array}{c}\text { No. } \\
\text { of } \\
\text { Teeth }\end{array}$ & $\%$ & $\begin{array}{c}\text { No. } \\
\text { of } \\
\text { Teeth }\end{array}$ & $\%$ & $\begin{array}{c}\text { No. } \\
\text { of } \\
\text { Teeth }\end{array}$ & $\%$ & $\begin{array}{c}\text { No. } \\
\text { of } \\
\text { Teeth }\end{array}$ & $\%$ & $\begin{array}{c}\text { No. } \\
\text { of } \\
\text { Teeth }\end{array}$ & $\%$ & $\begin{array}{l}\text { No. } \\
\text { of } \\
\text { Teeth }\end{array}$ & $\%$ \\
\hline 11 & 542 & 377 & 69.6 & 263 & 48.5 & 151 & 27.9 & 346 & 63.8 & 435 & 80.3 & 87 & 16.0 \\
\hline 13 & 464 & 406 & 87.5 & 297 & 64.0 & 265 & 57.1 & 332 & 71.6 & 421 & 90.7 & 175 & 37.7 \\
\hline 15 & 392 & 343 & 87.5 & 267 & 68.1 & 265 & 67.6 & 315 & 80.4 & 353 & 90.0 & 225 & 57.4 \\
\hline 17 & 217 & 206 & 94.9 & 171 & 78.8 & 184 & 84.8 & 194 & 89.4 & 201 & 92.6 & 147 & 67.7 \\
\hline
\end{tabular}

TABLE VII-A

Plaque Score for Individual Teeth (Urban and Rural)

\begin{tabular}{c|c|c|c|c|c|c|c|c}
\hline Age & $\begin{array}{c}\text { Number } \\
\text { Examined }\end{array}$ & $\begin{array}{c}\text { Tooth } \\
\# 3\end{array}$ & $\begin{array}{c}\text { Tooth } \\
\# 9\end{array}$ & $\begin{array}{c}\text { Tooth } \\
\# 12\end{array}$ & $\begin{array}{c}\text { Tooth } \\
\# 19\end{array}$ & $\begin{array}{c}\text { Tooth } \\
\# 25\end{array}$ & $\begin{array}{c}\text { Tooth } \\
\# 28\end{array}$ & $\begin{array}{c}\text { Mean } \\
\text { Plaque }\end{array}$ \\
\hline 11 & 542 & 2.00 & 1.70 & 1.50 & 1.91 & 1.98 & 1.61 & 1.83 \\
13 & 464 & 1.95 & 1.55 & 1.58 & 1.85 & 1.95 & 1.59 & 1.75 \\
15 & 392 & 1.89 & 1.59 & 1.52 & 1.80 & 1.77 & 1.56 & 1.67 \\
17 & 217 & 1.74 & 1.54 & 1.53 & 1.76 & 1.79 & 1.52 & 1.65 \\
\hline
\end{tabular}

$T_{\text {ABLE }}$ VII-B

Individual Teeth with Plaque (Urban and Rural)

\begin{tabular}{|c|c|c|c|c|c|c|c|c|c|c|c|c|c|}
\hline \multirow[b]{2}{*}{ Age } & \multirow[b]{2}{*}{$\begin{array}{l}\text { Number } \\
\text { Examined }\end{array}$} & \multicolumn{2}{|c|}{ Tooth \#3 } & \multicolumn{2}{|c|}{ Tooth \#9 } & \multicolumn{2}{|c|}{ Tooth \#12 } & \multicolumn{2}{|c|}{ Tooth \#19 } & \multicolumn{2}{|c|}{ Tooth \#25 } & \multicolumn{2}{|c|}{ Tooth \#28 } \\
\hline & & $\begin{array}{c}\text { No. } \\
\text { of } \\
\text { Teeth }\end{array}$ & $\%$ & $\begin{array}{c}\text { No. } \\
\text { of } \\
\text { Teeth }\end{array}$ & $\%$ & $\begin{array}{c}\text { No. } \\
\text { of } \\
\text { Teeth }\end{array}$ & $\%$ & $\begin{array}{c}\text { No. } \\
\text { of } \\
\text { Teeth }\end{array}$ & $\%$ & $\begin{array}{c}\text { No. } \\
\text { of } \\
\text { Teeth }\end{array}$ & $\%$ & $\begin{array}{c}\text { No. } \\
\text { of } \\
\text { Teeth }\end{array}$ & $\%$ \\
\hline 11 & 542 & 538 & 99.3 & 502 & 92.6 & 386 & 71.2 & 493 & 91.0 & 513 & 94.6 & 297 & 54.8 \\
\hline 13 & 464 & 459 & 98.9 & 435 & 93.8 & 421 & 90.7 & 445 & 95.9 & 451 & 97.2 & 396 & 85.3 \\
\hline 15 & 392 & 386 & 98.5 & 377 & 96.2 & 374 & 96.9 & 370 & 94.4 & 3.76 & 95.9 & 360 & 91.8 \\
\hline 17 & 217 & 214 & 98.6 & 217 & 100.0 & 217 & 100.0 & 217 & 100.0 & 208 & 95.9 & 209 & 96.3 \\
\hline
\end{tabular}


$T_{\text {ABLE }}$ VIII

Mean Scores for Attrition, Mobility and Open Contact (Urban and Rural)

\begin{tabular}{c|c|c|c|c}
\hline Age & $\begin{array}{c}\text { Number } \\
\text { Examined }\end{array}$ & Attrition & Mobility & Contact \\
\hline 11 & 542 & .57 & .02 & .19 \\
13 & 464 & .65 & .01 & .17 \\
15 & 392 & .75 & .01 & .17 \\
17 & 217 & .92 & .02 & .19 \\
\hline
\end{tabular}

table. There are no significant variations in mobility and open contacts in these young age groups. The percentage of the teeth examined that showed evidence of attrition is recorded in Table IX. The increase of attrition with age and its relation to the number of years that the teeth have been present in the mouth can be observed from this table.

From Table $\mathrm{X}$, it is evident that tooth \#25 exhibited abnormal mobility more of ten than the other teeth examined. About 5 per cent of the mandibular right central incisors showed a non-physiologic degree of mobility. From clinical observation, it was evident that this increased mobility was due to (1) obvious malposition and (2) severe periodontal inflammation. The figures for mobility for the rest of the teeth are insignificant in this material of young individuals.

Open contacts were observed most commonly around tooth \#9 according to Table XI. About one-third to one-fourth of these teeth had open contacts. There was no distinct age distribution for the open contacts. Open contacts were observed much more rarely around the upper and lower first molars.

A cursory attempt was made to compare the methods of oral hygiene with the score for periodontal disease (Table XII), but the number of individuals using brush and datan stick was too small to serve as a basis for an evaluation of these various methods. Seemingly, the use of a brush was associated with a slightly lower periodontal disease score than the other methods of oral hygiene. It should be emphasized that the inadequate brushes used and the haphazardous way they were used do not in any way allow an evaluation of the value of tooth brushing in the prevention of periodontal disease.

The mean depth of the gingival crevice of all teeth examined (Table XIII) shows only a slight variation with age. A small decrease in crevice depth with increase in age is noted on the buccal and lingual side of the teeth, while the interproximal crevice depth is unaltered or slightly increased.

Table XIV shows the mean periodontal

TABLE IX

Individual Teeth with Attrition (Urban and Rural)

\begin{tabular}{|c|c|c|c|c|c|c|c|c|c|c|c|c|c|}
\hline \multirow[b]{2}{*}{ Age } & \multirow[b]{2}{*}{$\begin{array}{l}\text { Number } \\
\text { Examined }\end{array}$} & \multicolumn{2}{|c|}{ Tootb \#3 } & \multicolumn{2}{|c|}{ Tooth \#9 } & \multicolumn{2}{|c|}{ Tooth \#12 } & \multicolumn{2}{|c|}{ Tooth \#19 } & \multicolumn{2}{|c|}{ Tooth \#25 } & \multicolumn{2}{|c|}{ Tooth \#28 } \\
\hline & & $\begin{array}{c}\text { No. } \\
\text { of } \\
\text { Teeth }\end{array}$ & $\%$ & $\begin{array}{c}\text { No. } \\
\text { of } \\
\text { Teeth }\end{array}$ & $\%$ & $\begin{array}{c}\text { No. } \\
\text { of } \\
\text { Teeth }\end{array}$ & $\%$ & $\begin{array}{c}\text { No. } \\
\text { of } \\
\text { Teeth }\end{array}$ & $\%$ & $\begin{array}{c}\text { No. } \\
\text { of } \\
\text { Teeth }\end{array}$ & $\%$ & $\begin{array}{c}\text { No. } \\
\text { of } \\
\text { Teeth }\end{array}$ & $\%$ \\
\hline 11 & 542 & 324 & 59.8 & 334 & 61.6 & 89 & 16.4 & 348 & 64.2 & 255 & 47.0 & 31 & 5.7 \\
\hline 13 & 464 & 359 & 77.4 & 342 & 73.7 & 167 & 36.0 & 383 & 82.5 & 299 & 64.4 & 103 & 22.2 \\
\hline 15 & 392 & 318 & 81.1 & 333 & 84.9 & 198 & 50.5 & 325 & 82.9 & 297 & 75.8 & 138 & 35.2 \\
\hline 17 & 217 & 200 & 92.2 & 197 & 90.8 & 152 & 70.0 & 179 & 82.5 & 195 & 89.9 & 118 & 54.4 \\
\hline
\end{tabular}


$\mathrm{T}_{\text {ABLE }} \mathrm{X}$ Individual Teeth with Mobility (Urban and Rural)

\begin{tabular}{|c|c|c|c|c|c|c|c|c|c|c|c|c|c|}
\hline \multirow[b]{2}{*}{ Age } & \multirow[b]{2}{*}{$\begin{array}{l}\text { Number } \\
\text { Examined }\end{array}$} & \multicolumn{2}{|c|}{ Tooth \#3 } & \multicolumn{2}{|c|}{ Tootb \#9 } & \multicolumn{2}{|c|}{ Tooth \#12 } & \multicolumn{2}{|c|}{ Tooth \#19 } & \multicolumn{2}{|c|}{ Tooth \#25 } & \multicolumn{2}{|c|}{ Tooth \#28 } \\
\hline & & $\begin{array}{c}\text { No. } \\
\text { of } \\
\text { Teeth }\end{array}$ & $\%$ & $\begin{array}{c}\text { No. } \\
\text { of } \\
\text { Teeth }\end{array}$ & $\%$ & $\begin{array}{c}\text { No. } \\
\text { of } \\
\text { Teeth }\end{array}$ & $\%$ & $\begin{array}{c}\text { No. } \\
\text { of } \\
\text { Teeth }\end{array}$ & $\%$ & $\begin{array}{c}\text { No. } \\
\text { of } \\
\text { Teeth }\end{array}$ & $\%$ & $\begin{array}{c}\text { No. } \\
\text { of } \\
\text { Teeth }\end{array}$ & $\%$ \\
\hline 11 & 542 & 1 & .18 & 2 & .37 & 0 & 0 & 3 & .55 & 38 & 7.0 & 0 & 0 \\
\hline 13 & 464 & 2 & .43 & 1 & .22 & 0 & 0 & 4 & .86 & 19 & 4.0 & 2 & .43 \\
\hline 15 & 392 & 0 & 0 & 3 & .77 & 0 & 0 & 0 & 0 & 20 & 5.1 & 2 & .51 \\
\hline 17 & 217 & 0 & 0 & 1 & .46 & 2 & .92 & 1 & 46 & 11 & 5.0 & 0 & 0 \\
\hline
\end{tabular}

disease index (P.D.I.) for the various groups examined indicating a slow, gradual increase in severity of periodontal disease with age.

The caries problem in the permanent teeth seemed negligible in our material, while remaining deciduous teeth usually were totally broken down by caries as reported by Chaudhry et $\mathrm{al}^{8}$ from another area of India. Some cases of arrested caries were observed in the occlusal surfaces of the first molars. Occlusal wear in these areas of arrested caries gave the appearance of deep and wide occlusal fissures with a rounded bottom, almost as though the fissure had been deepened with a \#8 round bur.

No attempt was made to investigate the occurrence of caries, but from casual inquiry, it appeared that babies and small children often drank a heavy sugar solution. Later, when they entered school, this was considered "baby stuff" and its use was discontinued.

\section{SIGNIFICANCE OF FINDINGS}

The results should be evaluated in relation to the five objectives listed in the introduction.

1. The limited time and restricted facilities available did not allow for satisfactory training and calibration of the examiners assigned to this study. The relatively few subjects examined by some of the examiners and the simultaneous use of two similar, but in some respects different, scoring methods also detracted from the reliability of the collected data. An attempt was made to analyze statistically the comparability of the examiners, but too few subjects had been examined by the individual examiner to make this analysis meaningful. (A limited number of copies of the detailed report submitted to the W.H.O. is available upon request to the author.) A very close comparability of scores existed among the three to four examiners who were given the most instruction and supervision. Therefore, it can be

TABLE XI

Individual Teeth with Open Contacts (Urban and Rural)

\begin{tabular}{|c|c|c|c|c|c|c|c|c|c|c|c|c|c|}
\hline \multirow[b]{2}{*}{ Age } & \multirow[b]{2}{*}{$\begin{array}{r}\text { Number } \\
\text { Examined }\end{array}$} & \multicolumn{2}{|c|}{ Tooth \#3 } & \multicolumn{2}{|c|}{ Tooth \#9 } & \multicolumn{2}{|c|}{ Tooth \#12 } & \multicolumn{2}{|c|}{ Tooth \#19 } & \multicolumn{2}{|c|}{ Tooth \#25 } & \multicolumn{2}{|c|}{ Tooth \#28 } \\
\hline & & $\begin{array}{c}\text { No. } \\
\text { of } \\
\text { Teeth }\end{array}$ & $\%$ & $\begin{array}{c}\text { No. } \\
\text { of } \\
\text { Teeth }\end{array}$ & $\%$ & $\begin{array}{c}\text { No. } \\
\text { of } \\
\text { Teetb }\end{array}$ & $\%$ & $\begin{array}{c}\text { No. } \\
\text { of } \\
\text { Teeth }\end{array}$ & $\%$ & $\begin{array}{c}\text { No. } \\
\text { of } \\
\text { Teeth }\end{array}$ & $\%$ & $\begin{array}{c}\text { No. } \\
\text { of } \\
\text { Teeth }\end{array}$ & $\%$ \\
\hline 11 & 542 & 15 & 2.8 & 145 & 26.8 & 73 & 13.5 & 24 & 4.4 & 46 & 8.5 & 54 & 10.0 \\
\hline 13 & 464 & 23 & 5.0 & 133 & 28.7 & 72 & 15.5 & 18 & 3.4 & 51 & 11.0 & 73 & 15.7 \\
\hline 15 & 392 & 13 & 3.3 & 103 & 26.3 & 65 & 16.6 & 13 & 3.3 & 69 & 17.6 & 64 & 16.3 \\
\hline 17 & 217 & 3 & 1.4 & 72 & 33.2 & 31 & 14.3 & 10 & 4.6 & 38 & 17.5 & 35 & 16.1 \\
\hline
\end{tabular}


Table XII

Method of Oral Hygiene Related to Periodontal Disease (Urban and Rural)

\begin{tabular}{c|l|c|c}
\hline \multirow{2}{*}{ Age } & \multicolumn{1}{|c|}{ Method of Cleaning } & $\begin{array}{c}\text { Number } \\
\text { Examined }\end{array}$ & $\begin{array}{c}\text { Mean Periodontal } \\
\text { Disease Score }\end{array}$ \\
11 & Brush plus powder or paste & 13 & 1.18 \\
& Finger plus abrasive & 514 & 1.40 \\
& Stick & 15 & 1.72 \\
13 & Brush plus powder or paste & 17 & 1.56 \\
& Finger plus abrasive & 388 & 1.49 \\
& Stick & 15 & 1.43 \\
& Brush plus powder or paste & 33 & 1.48 \\
& Finger plus abrasive & 371 & 1.70 \\
& Stick & 25 & 1.58 \\
& Brush plus powder or paste & 31 & 1.44 \\
& Finger plus abrasive & 165 & 1.58 \\
& Stick & 25 & 1.52 \\
\hline
\end{tabular}

concluded that the method would provide good comparability of examiners following adequate training.

2. Epidemiology of periodontal disease in India has been more thoroughly investigated than in most parts of the world. Marshall-Day and Shourie's pioneer surveys $^{9-12}$ have been followed by very fine investigations by Mehta, Sanjana, and others. ${ }^{13-16}$ These studies, supported by the present report, have established a prevalence rate of periodontal disease so close to 100 per cent that further prevalence studies in similar population groups apparently will be of very limited value. However, the available information on incidence, severity, and quantitation of periodontal destruction is highly incomplete and controversial. The main emphasis in the present study, therefore, was directed toward an accurate clinical registration of the periodontal status in the subjects that were examined. The main shortcoming with all of the previously used recording systems for periodontal disease is the lack of orientation of the periodontal pockets that makes attempts to quantitate periodontal destruction unreliable or meaningless. The cementum-enamel junction provides a natural landmark for recording of periodontal pockets, ${ }^{1}$ and only when this landmark is used can it be ascertained clinically whether or not periodontal sup- port has been lost. Controlled conditions for such recordings requires suitable instruments and well-trained investigators in order to achieve results in clinical research that in reliability and significance can match the fine laboratory investigations in current dental research.

By far the most important finding in the present study was that the clinically measurable destruction of periodontal attachment to the tooth started around the age of 15 years. True periodontal pockets or gingival recession apically to the cementum-enamel junction were observed in more than 12 per cent of the boys at the age of 17 years (Table III), while 3 per cent had only an insignificant early loss of periodontal support at the age of 15 years. Obviously, this means that periodontal treatment should be initiated before the age of 15 years in order to safeguard against permanent loss of periodontal support under the conditions of the present study.

The figures for periodontal pockets and gingival recession (Table III, bottom) in subjects between 19 and 30 years of ige show that 42.4 per cent had true periodontal pockets and 27 per cent had gingival recession apically to the cementum-enamel junction, indicating that 70 per cent of the subjects in this group had experienced permanent loss of periodontal support. 
TABLE XIII

Mean Crevice Depth of All Teeth Examined

\begin{tabular}{c|c|c|c|c|c}
\hline Age & $\begin{array}{c}\text { Number } \\
\text { Examined }\end{array}$ & Mesial & Distal & Buccal & Lingual \\
\cline { 2 - 3 } 11 & 542 & 2.69 & 2.53 & 2.04 & 1.92 \\
13 & 464 & 2.75 & 2.61 & 1.94 & 1.86 \\
15 & 392 & 2.71 & 2.63 & 1.82 & 1.84 \\
17 & 217 & 2.76 & 2.63 & 1.71 & 1.75 \\
\hline
\end{tabular}

These figures are considerably higher than the figures for pocket formation reported by Greene ${ }^{2}$ for the same group. This difference is probably due to a routine probing with a fine probe in the present study compared with probing with a scaler in areas where the presence of pockets is strongly suspected in compliance with the Russell method ${ }^{17}$ used by Greene. ${ }^{2}$

The noted slight decrease in severity of gingivitis from 13 or 15 years of age to 17 years was counterbalanced in the P.D.I. scores (Table XIV) by the onset of pocket formation and gingival recession in these groups indicating a slowly progressing destruction associated with chronic periodontal disease in spite of a light improvement of the gingival inflammation.

The "statistically significant" difference in P.D.I. between the rural and urban groups in Table I has already been discussed. A warning should be made against implying too much significance to small so-called "statistically significant" variations in surveys of this type since the mathematical signifiance according to statistical methods may be clinically insignificant. Furthermore, statistics should be applied with great caution to clinical material where the basic data are dependent upon the ability of the examiner to observe, assess, and record rather subtile clinical variations.

3. Several factors that generally are considered important in the etiology of periodontal disease were studied.

The tremendous accumulation of calculus in these young individuals and the practically non-existent oral hygiene dominated completely over the other sources of gingival irritation. The gradual increase in amount of calculus and number of teeth with calculus with age is demonstrated in Tables VI-A and VI-B. By comparing calculus scores from Table VI-A with gingivitis scores for the same teeth in Table IV an obvious correlation appears between these two conditions. Even more convincing is the relationship between teeth with pockets (Table $V_{-A}$ ) and the calculus scores for the same teeth (Table VI-A). A cause and effect relationship between calculus and periodontal disease has been reported by practically every investigator in this field since King's study ${ }^{19}$ in 1945 .

No explanation appeared for the severe and early calculus formation noted in the present and other investigations from Asia ${ }^{2,3,5,9-12,16,20,21}$ and North Africa. ${ }^{22}$ Neither the physical properties of the diet nor the nutritional values of the food were studied. However, in future studies of calculus formation in similar populations the diet should be given due attention. Chewing of betel leaves had nothing to do with

TABLE XIV

Periodontal Disease Index for Urban and Rural Groups Combined

\begin{tabular}{c|c|c}
\hline Age & $\begin{array}{c}\text { Number } \\
\text { Examined }\end{array}$ & $\begin{array}{c}\text { Total } \\
\text { Periodontal Index }\end{array}$ \\
\hline 11 & 542 & 1.40 \\
13 & 464 & 1.50 \\
15 & 392 & 1.54 \\
17 & 217 & 1.56 \\
\hline
\end{tabular}


the calculus formation reported in the present study, since very few of these young boys indulged in that habit.

The calculus was soft and easily removed in the 11 and 13 year old boys; but in the 17 year old group, the calculus was much harder and more difficult to remove. The ease by which the calculus can be removed before 15 years of age and the onset of pocket formation at this age are both factors that should encourage the calculus removal before the age of 15 years.

No apparent correlation was found between the gingivitis and plaque scores for the individual teeth (Tables IV and VII-A). However, an indefinite correlation appeared between the gingivitis score (Table IV) and the percentage of teeth with bacterial plaques (Table VII-B). Chawla and coworkers, ${ }^{23}$ using the scoring methods that were used in the present study for an age group from 12 to 30 years, found a progressive increase in the number of teeth that had the highest gingivitis score as the plaque score increased. The same trend can be found in Table I when the age group from 19 to 30 years of age is considered; however, multiple correlation tests with other etiologic factors were not done.

It is evident from clinical observation that the gingival part of the coronal plaque is the main source of the gingival irritation, and how much of the rest of the crown that is covered in very extensive plaque formation is apparently of lesser importance.

The present investigation of these young boys with early periodontal disease did not provide a suitable material for study of a possible relationship between attrition, mobility, open contacts, and the progress of periodontal disease.

4. All periodontal disease observed was clearly of inflammatory nature (gingivitis and periodontitis). In view of the overwhelming magnitude of the local irritants, especially calculus and bacterial plaques, and in spite of markedly retarded growth and apparent undernourishment among the majority of the examined subjects, the periodontal resistance to pocket formation must be considered surprisingly good in these young age groups.

Not a single case was observed that possibly could fit into the common clinical description of so-called "periodontosis." One or two individuals could be said to have "juvenile periodontitis," but they had considerable accumulation of calculus and severe inflammation. The only difference between these individuals and the rest of the subjects was in the degree of periodontal destruction rather than any difference in kind of disease.

5. The most significant finding related to management and prevention of periodontal disease in India was the determination of the age for onset of permanent periodontal destruction to about 15 years of age under the conditions of the present investigation. This observation has encouraged planning and initiation of an extensive program for oral prophylaxis in school children in India. ${ }^{24}$ However, the main reason for the severe periodontal problem in India, the tremendous calculus formation, remains unexplained.

The findings with regard to methods for oral hygiene were inconclusive (Table XII) although the tendency was to confirm the observations of Chawla and coworkers $^{23}$ that datan sticks were better than the use of fingers, and toothbrushes were better than the use of datan sticks.

\section{CONCLUSIONS}

1. Almost 100 per cent of the individuals examined had periodontal disease.

2. True periodontal pockets did not occur to any significant extent before the age of 15 years.

3. The periodontal disease increased slowly in severity with increasing age, although gingival inflammation decreased slightly in the middle teens. 
4. The amount of calculus increased with age.

5. The amount of bacterial plaques decreased from 11 to 15 or 17 years of age; later it increased.

6. A direct relationship was observed between the amount of calculus and the severity of periodontal disease.

7. The most severe gingival inflammation and pocket formation occurred around the lower incisors and the maxillary first molars. These teeth also had the highest calculus scores.

8. The lowest P.D.I. score was for the mandibular first bicuspid.

9. All periodontal disease was clearly of inflammatory nature (gingivitis and periodontitis).

\section{BIBLIOGRAPHY}

1. Ramfjord, S. P. Indices for prevalence and incidence of periodontal disease. $\mathrm{J}$. Periodont., 30:51-9, Jan. 1959.

2. Greene, J. C. Periodontal disease in India: Report of an epidemiological study. J. Dent. Res., 39:302-12, Mar.-Apr. 1960.

3. Marshall-Day, C. D., Stephens, R. G., and Quigley, L. F., Jr. Periodontal disease prevalence and incidence. J. Periodont., 26:185-203, July 1955.

4. Parfitt, G. J. Five year longitudinal study of the gingival condition of a group of children in England. J. Periodont., 28:26-32, Jan. 1957.

5. Mehta, F. S., Sanjana, M. K., Shroff, B. C., and Doctor, R. H. Follow-up study of the gingival aspects of periodontal disease and the local factors involved in its etiology amongst a group of school children in India. J. All India D. A., 31:55-62, Apr. 1959.

6. Mühlemann, H. R., and Mazor, Z. S. Gingivitis in Zurich school children. Helv. Odont. Acta 2:3-12, Apr. 1958 .

7. Parfitt, G. J. A survey of the oral health of Navajo Indian children. Arch. of Oral Biol., 1:193205, Jan. 1960.

8. Chaudhry, K. P., et al. Dental health survey of Lucknow school-going children. J. All India D. A., 29:199-205, Oct. 1957.

9. Marshall-Day, C. D., and Shourie, K. L. Incidence of periodontal disease in Punjab. Indian J.
Med. Res., 32:47, May 1944.

10. - Hypertrophic gingivitis in Indian children and adolescents. Indian J. M. Res., 3 5:261, Oct. 1947.

11. A roentgenographic survey of periodontal disease in India. J. A. D. A., 39:572-88, Nov. 1949.

12. Marshall-Day, C. D. The epidemiology of periodontal disease. J. Periodont., 22:13-23, Jan. 1951.

13. Mehta, F. S., Sanjana, M. K., Barretto, M. A., and Doctor, R. H. Relation of betel leaf chewing to periodontal disease. J. A. D. A., 50:531-6, May 1955 .

14. Mehta, F. S., Sanjana, M. K., and Shroff, B. C. Prevalence of periodontal (parodontal) disease. 5. Epidemiology in Indian child population in relation to their socio-economic status. Internat. D. J., 6:31-40, Mar. 1956 .

15. Sanjana, M. K., Mehta, F. S., Doctor, R. H., and Barretto, M. A. Mouth hygiene habits and their relation to periodontal disease. J. Dent. Res., 35 5:6457, Aug. 1956.

16. Sanjana, M. K., Mehta, F. S., Doctor, R. H., and Shroff, B. C. Study of the relative importance of the various local factors involved in the etiology of gingival aspect of periodontal disease. J. All India D. A., 30:55-8, Apr. 1958.

17. Russell, A. L. System of classification and scoring for prevalence surveys of periodontal disease. J. Dent. Res., 35:350-9, June 1956.

18. Lovdal, A., Arno, A., and Waerhaug, J. Incidence of clinical manifestations of periodontal disease in light of oral hygiene and calculus formation. J. A. D. A., 56:21-33, Jan. 1958.

19. King, J. D. Gingival disease in Dundee. D. Record, 65:9-16, Jan.; 32-8, Feb.; 55-60, Mar. 1945 .

20. Ladavalya, M. R. N., and Harris, R. Study of the gingival and periodontal conditions of a group of people in Chieng Mai Province. J. Periodont., 30:219-22, July 1959.

21. Parma, C. Reihenuntersuchung der parodontopathien. Deutsche Zahn-Mund und Kieferheilkunde, 29:132-9, Sept. 1958.

22. Dawson, C. E. Dental defects and periodontal disease in Egypt, 1946-1947. J. Dent. Res., 27:512-23, Aug. 1948 .

23. Chawla, T. N., Nanda, R. S., and Mathur, M. N. Bacterial plaque and its relation to periodontal disease. J. All India D. A., 31:121-5, Aug. 1959.

24. Bery, N. N. Presidential address to the Dental Council of India, March 8, 1960. Mimeographed material. 